\title{
Active biomonitoring of a subtropical river using glutathione-S-transferase (GST) and heat shock proteins (HSP 70) in Oreochromis niloticus as surrogate biomarkers of metal contamination
}

\author{
Victor Kurauone Muposhi', Beaven Utete ${ }^{1 *}$, Idah Sithole-Niang² and Stanley Mukangenyama ${ }^{2}$ \\ 'Wildlife Ecology and Conservation, Chinhoyi University of Technology, P. Bag 7724, Chinhoyi, Zimbabwe \\ ${ }^{2}$ Department of Biochemistry, University of Zimbabwe, P O Box MP 167, Mt Pleasant, Harare, Zimbabwe
}

\begin{abstract}
The aim of this study was to establish the level of water quality impairment along a mine effluent receiving river, Pote River in Zimbabwe, using Oreochromis niloticus (Nile tilapia) as an indicator organism. Glutathione-S-transferase (GST) enzyme and heat shock protein (HSP 70) expression in the stomach tissue of Nile tilapia were used as biomarkers of heavy metal pollution. Water and fish samples were collected at three sites in the Pote River. Metal concentration in tilapia tissues and water were measured using flame acetylene absorption spectrophotometry while enzymatic activity was determined using ultra-violet spectrophotometry. The concentration of $\mathrm{Ni}$ and $\mathrm{Zn}$ in water was significantly high compared to the World Health Organization aquatic effluent standards. Cd and Zn were strongly associated with high GST activity and low HSP 70 protein concentrations in fish tissues. Results of this study show that HSP 70 protein and GST enzyme activity can be useful biomarkers of metal contamination in lotic systems.
\end{abstract}

Keywords: enzymes, biomarkers, heavy metals, Nile tilapia, bioassessment, Pote River

\section{INTRODUCTION}

Heavy metals present a significant ecological and public health concern due to their toxicity and ability to bioaccumulate in organisms (Adeniyi, 2008). Accumulation and persistence of heavy metals in the aquatic environment constitute a threat to biological life as shown by the chronic and acute poisoning of fish and other aquatic organisms (Haiyan and Stuanes, 2003). Potential long-term adverse effects of heavy metals on aquatic organisms include cancer (Amaranemi, 2006) and reproductive impairments (Iwegbu, 2007), hence making appropriate monitoring and control measures an imperative.

The development of fish-based biomonitoring techniques offers an effective and reliable tool to monitor water pollution (Jatto et al., 2010). The Nile tilapia, Oreochromis niloticus, is responsive to heavy metals in various ways and has the potential to be used as a bioindicator organism of aquatic system impairment (Egbon et al., 2006). This species has been observed to be sensitive to heavy metal contamination using enzyme biomarkers (acid phosphatase (AP), glutamic oxaloacetic transaminase (GOT), and glutamic pyruvic transaminase (GPT)) (Adedeji, 2011). Farombi et al. (2007) show that O. niloticus is a useful bioindicator of heavy metal impairment through biomarkers of oxidative stress, glutathione-S-transferase (GST) and glutathione (GSH) in aquatic ecosystems. These biomarkers present transient and spatially integrated measures of bioavailable pollutants in ecosystems (Hook and Fisher, 2002). The applicability of biomarkers in the laboratory as well as in the field offers a consolidated river system monitoring programme (Hook, 2001).

Heavy metals that accumulate in fish tissue may catalyse reactions that generate oxygen reactive species (ROS) which lead

* To whom all correspondence should be addressed.

e-mail: butete@cut.ac.zw; beavenu@yahoo.co.uk

Received 18 February 2014; accepted in revised form 12 March 2015 to oxidative stress (Siwela et al., 2009). Defensive mechanisms to counteract ROS are found in many aquatic organisms including fish. These mechanisms include various antioxidant enzymes, such as glutathione-s-transferase (GST), which possess detoxifying activities towards lipid hydroperoxides generated by organic pollutants as well as heavy metals (Farombi et al., 2007). Heat shock protein (HSP 70) expression has been used as a stress biomarker of environmental toxicity emanating from effluent discharges in freshwater ecosystems (Wepener et al., 2005). The objective of this study was to establish the level of impairment along an effluent receiving stream, the Pote River in Zimbabwe, using O. niloticus as an indicator organism and using GST and HSP 70 as surrogate biomarkers of heavy metals.

\section{METHODS}

\section{Study area}

Three sites along Pote River were selected; Site A ( $17^{\circ} 20^{\prime} 05.00^{\prime \prime} \mathrm{S}$ $\left.31^{\circ} 18^{\prime} 29.68^{\prime \prime} \mathrm{E}\right)$; Site B (1720'58.88”S $\left.31^{\circ} 19^{\prime} 31.38^{\prime \prime} \mathrm{E}\right)$; Site C $\left(17^{\circ} 21^{\prime} 29.57^{\prime \prime} \mathrm{S} 31^{\circ} 20^{\prime} 05.18^{\prime \prime} \mathrm{E}\right)$. These sites were selected due to their close proximity to the main smelters at Bindura Nickel Mine and the tailings dam, which directly discharge acid- and metal-laden mine effluent. Site A was the closest to the mine complex and had rocky habitats. Site B had rocks and exotic weeds in the riparian vegetation and Site $\mathrm{C}$ was dominated by Phragmites sp. The fourth site was the Henderson Research Station where the fish samples were obtained, and was regarded as the reference site (Fig 1).

\section{Fish sample collection}

Eighty (80) fish samples (Oreochromis niloticus) were collected from ponds at Henderson Research Station Fisheries Section and were deemed free from pollution. Fish with the same aver age weight $(6.00 \pm 1.30 \mathrm{~g})$ and average length $(5 \pm 1.32 \mathrm{~cm})$ were used for the tests. The live fish were kept in specially designed 


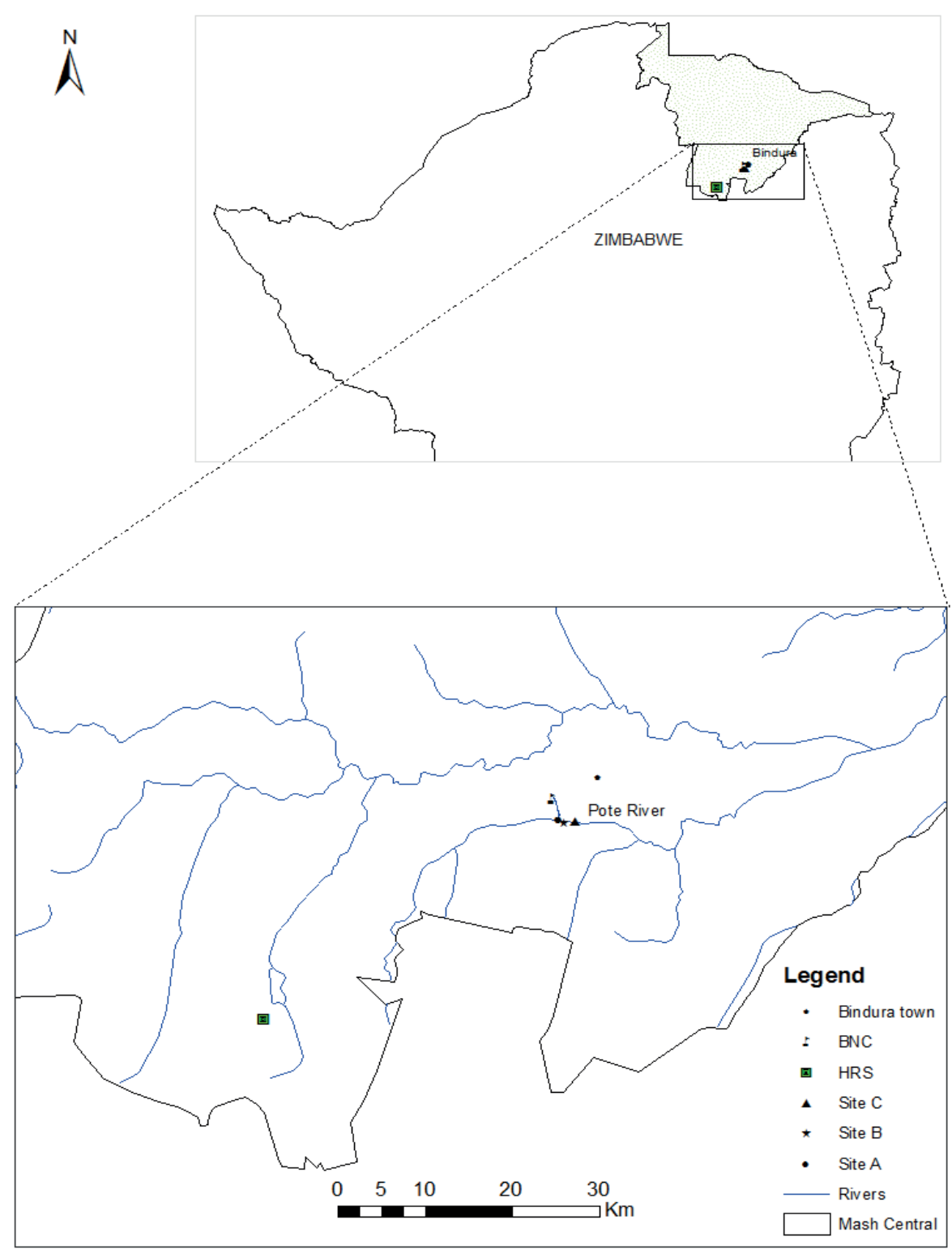

Figure 1

Map showing sites sampled along the Pote River

Perspex cages $(45 \times 30 \times 30 \mathrm{~cm})$, in duplicate at each site as well as the control site. Each cage was stocked with 10 fish and set in situ at the 4 sampling sites for 6 weeks. To reduce stress related to feed accessibility, fish were fed pellets obtained from the research station for the entire study period. Ten fish were subsampled randomly at cage setting (0 weeks), and after 3 and 6 weeks for metal analysis. The fish were later dissected using sterilized stainless steel instruments to remove tissues and gills, which were immediately immersed in liquid nitrogen and stored at $-80^{\circ} \mathrm{C}$ until analysis.

\section{Water quality sample collection}

Surface water was collected from the sampling sites for heavy metal analysis in sterilized $250 \mathrm{~m} \ell$ polyethylene bottles before fish were collected, at Weeks 0,3 and 6 . The following variables were measured on-site, temperature, $\mathrm{pH}$, conductivity and dissolved oxygen (DO), using a $\mathrm{HACH}$ pH meter, WTW 330i conductivity meter and $\mathrm{HACH}$ oxygen $330 \mathrm{i}$ meter, respectively.
The $250 \mathrm{~m} \ell$ polyethylene bottles were taken to the laboratory and immediately refrigerated at a temperature of $4^{\circ} \mathrm{C}$. In the laboratory the water samples were filtered through $0.45 \mu \mathrm{m}$ pore sized Whatman G/F filters into sterilized $100 \mathrm{~m} \ell$ volumetric flasks. The filtered samples were acidified with nitric acid to a $\mathrm{pH}$ less than 2. Estimation of the heavy metals was conducted using air/ acetylene flame atomic absorption spectrophotometry (AAS).

\section{Laboratory procedures}

In the laboratory, fish were dissected with clean autoclaved stainless steel instruments. One gram (wet weight) of abdominal muscle tissue of $O$. niloticus was measured using an electronic balance. Fish tissue digestion was done following the USEPA (3050 protocol). The abdominal muscle tissues were placed into Petri dishes to dry at $120^{\circ} \mathrm{C}$ until they reached a constant weight. Dry abdominal muscle tissues were placed in digestion flasks to which $5 \mathrm{~m} \ell$ perchloric acid and $10 \mathrm{~m} \ell$ nitric acid were added. All acids used were of analytical grade quality. The digestion flasks 
were placed in an oven at $130^{\circ} \mathrm{C}$ until all materials dissolved. The heavy metals in the O. niloticus abdominal muscle tissue were estimated by air/acetylene flame atomic absorption spectrophotometry (AAS). The following heavy metals were determined in the digested fish tissue: $\mathrm{Cu}, \mathrm{Pb}, \mathrm{Zn}, \mathrm{Cd}, \mathrm{Co}$ and $\mathrm{Ni}$.

The HSP 70 concentration was determined in the supernatant, which was kept at $-80^{\circ} \mathrm{C}$. The protein concentration for the samples was determined using the Bradford method (Bradford, 1976). The proteins were separated using sodium dodecysulphate polyacrylamide gel electrophoresis (SDS-PAGE). Separated proteins were transferred to a nitrocellulose membrane by western blotting at $30 \mathrm{~V}$ for $16 \mathrm{~h}$ at $40^{\circ} \mathrm{C}$. The transferred proteins were stained in Ponceau $\mathrm{S}$ for $15 \mathrm{~min}$. The nitrocellulose membrane was blocked for $3.5 \mathrm{~h}$ in non-fat dried milk containing $0.02 \%$ sodium azide, then incubated in HSP 70 primary antibody for $20 \mathrm{~h}$. The membrane was washed 3 times in phosphate-buffered saline and once in Tris-buffered saline for $10 \mathrm{~min}$, and then incubated in non-fat azide free blocking solution containing secondary HSP 70 antibody for $3 \mathrm{~h}$. The membrane was then washed in 4 changes of Tris-buffered saline before enhanced chemiluminescence (ECL) detection. ECL-Western blotting reagents (Amersham Pharmacia Biotech) were used to detect the HSP 70 proteins. The HSP 70 bands were quantified as relative intensities using UVP GRAB IT (image analyser) and Gene Tools from 19 Sygene, both from the same hyperfilm, and were expressed in arbitrary units.

GST activity was determined by the Habig et al. (1974) method using 1-chloro-2, 4-dinitrobenzene (CDNB) as substrate. Assays were performed on a mixture of $800 \mu \ell$ of $0.1 \mathrm{M}$ $\mathrm{NaPi}$ (pH 6.5), $100 \mu \ell$ tissue homogenate, $50 \mu \ell$ of $1 \mathrm{mM} \mathrm{GSH}$ and $1 \mathrm{mM}$ CDNB. The change in absorbance was measured at $340 \mathrm{~nm}$ for $60 \mathrm{~s}$ at $30^{\circ} \mathrm{C}$ using the Shimadzu UV spectrophotometer in the kinetics mode.

\section{Data analysis}

Analysis of variance (ANOVA) was used to analyse the physicochemical data. Biomarker data were tested for homogeneity of variance using the Levene's test. Friedman Anova test was used to compare the difference in metal concentration and enzyme activity over the 6-week period. Paired sample $t$-test as well as Kruskall Wallis ANOVA was used to test for differences in the biomarker responses between sites and exposure durations and metal concentrations in water. When ANOVA indicated that significant differences existed, Scheffe's multiple comparison tests were used. Spearman correlation tests further strengthened by the Kendall Tau tests were used to investigate the relationship between biomarker levels and metal concentrations in Tilapia tissues. Statistical tests were evaluated using the Paleontological Statistics (PAST) software Version 1, 90 (Hammer et al., 2012). Principal component analysis (PCA) to determine limnochemical parameters association with metals in the fish tissues was conducted using CANOCCO 5 (Ter Braak and Smilauer, 2012)

The bioconcentration factor (BCF) was calculated after metal concentrations were determined for water and fish tissues. The BCF is defined in this study as the concentration of a metal in a fish tissue in relation to the concentration of that metal in the water surrounding that tissue. The BCF in this study was calculated using the Wiener and Giesy (1979) formula:

$$
\text { Bioconcentation }=\frac{\text { Concentration of metals in sediments }}{\text { Concentration of metals in water }}
$$

BCF values greater than 1000 were considered high and those under 250 low, while those between these extremes were considered as moderate values.

\section{RESULTS}

\section{Water quality measurements}

Water quality measurement results for the Pote River are presented in Table 1. All sites in the Pote River were alkaline except Site A at Week 0. Dissolved oxygen levels were high at the control site and Sites A and C, while conductivity was high at Sites B and C. Temperature was high at the

\begin{tabular}{|c|c|c|c|c|}
\hline \multicolumn{5}{|c|}{$\begin{array}{c}\text { Table } 1 \\
\text { Levels of selected physicochemical water parameters (Mean } \pm \text { SD) at sites on the Pote River }\end{array}$} \\
\hline Parameter & Site & Week 0 & Week 3 & Week 6 \\
\hline \multirow[t]{4}{*}{ Temperature $\left({ }^{\circ} \mathrm{C}\right)$} & Control & $20.1 \pm 0.7$ & $20.3 \pm 0.6$ & $20.5 \pm 0.8$ \\
\hline & $\mathrm{A}$ & $18.2 \pm 3.6$ & $19.3 \pm 0.5$ & $19.6 \pm 3.1$ \\
\hline & B & $18.6 \pm 0.9$ & $18.7 \pm 3.2$ & $19.1 \pm 0.2$ \\
\hline & $\mathrm{C}$ & $20 \pm 0.6$ & $19.8 \pm 7.4$ & $20.2 \pm 3.6$ \\
\hline \multirow[t]{4}{*}{$\mathrm{DO}(\mathrm{mg} / \mathrm{l})$} & Control & $10.23 \pm 8.6$ & $10.21 \pm 0.1$ & $10.3 \pm 0.4$ \\
\hline & A & $9.21 \pm 0.2$ & $9.3 \pm 0.1$ & $8.72 \pm 0.5$ \\
\hline & $\mathrm{B}$ & $7.6 \pm 0.3$ & $6.51 \pm 0.7$ & $8.83 \pm 0.8$ \\
\hline & $\mathrm{C}$ & $9.45 \pm 3.1$ & $7.1 \pm 0.8$ & $8.6 \pm 0.7$ \\
\hline \multirow[t]{4}{*}{$\mathrm{pH}$} & Control & $7.52 \pm 0.8$ & $7.52 \pm 0.7$ & $7.53 \pm 0.5$ \\
\hline & $\mathrm{A}$ & $6.8 \pm 1.2$ & $7.1 \pm 3.2$ & $7.5 \pm 0.3$ \\
\hline & $\mathrm{B}$ & $7.8 \pm 0.7$ & $7.6 \pm 0.5$ & $7.92 \pm 0.6$ \\
\hline & $\mathrm{C}$ & $7.83 \pm 0.1$ & $8.1 \pm 0.3$ & $7.9 \pm 3.3$ \\
\hline \multirow[t]{4}{*}{ Conductivity $(\mathrm{S} / \mathrm{cm})$} & Control & $476 \pm 5.6$ & $469 \pm 5.8$ & $481 \pm 4.8$ \\
\hline & A & $521 \pm 6.7$ & $530 \pm 7.2$ & $593 \pm 6.4$ \\
\hline & $\mathrm{B}$ & $662 \pm 4.6$ & $631 \pm 6.3$ & $681 \pm 6.3$ \\
\hline & $\mathrm{C}$ & $536 \pm 7.8$ & $451 \pm 4.7$ & $563 \pm 4.3$ \\
\hline \multirow[t]{4}{*}{ TDS (mg/e) } & Control & $152 \pm 2.3$ & $153 \pm 1.5$ & $157 \pm 0.1$ \\
\hline & $\mathrm{A}$ & $185 \pm 4.2$ & $190 \pm 0.1$ & $186 \pm 2.3$ \\
\hline & $\mathrm{B}$ & $201 \pm 2.2$ & $198 \pm 0.4$ & $189 \pm 1.2$ \\
\hline & $\mathrm{C}$ & $202 \pm 0.1$ & $224 \pm 1.2$ & $223 \pm 3.2$ \\
\hline
\end{tabular}

http://dx.doi.org/10.4314/wsa.v41i3.15

Available on website http://www.wrc.org.za

ISSN 1816-7950 (On-line) = Water SA Vol. 41 No. 3 April 2015

Published under a Creative Commons Attribution Licence 
control and Site C. Total dissolved solid (TDS) levels were high at Site C. Significant differences ( $p<0.05$; Kruskall Wallis Anova) were observed for temperature, $\mathrm{DO}, \mathrm{pH}$, conductivity and TDS between the sites. Multiple comparison tests revealed strong differences ( $p<0.05$; Tukeys test) for temperature, $\mathrm{DO}, \mathrm{pH}$, and conductivity between Sites A and $\mathrm{B}$.

\section{Metals in water}

$\mathrm{Ni}$ and $\mathrm{Zn}$ concentrations in flowing water were higher than the World Health Organization standards (Table 2). Pb, Ni and $\mathrm{Zn}$ differed significantly ( $p<0.05$; Kruskall Wallis test) among all the sites. The paired $t$-tests revealed significant differences $(p<0.05)$ in $\mathrm{Pb}, \mathrm{Ni}, \mathrm{Zn}$ and $\mathrm{Cu}$ for all of the sites and the control. Friedman Anova tests revealed significant differences in $\mathrm{Pb}, \mathrm{Ni}$ and $\mathrm{Zn}$ across all the sites. Differences in $\mathrm{Pb}, \mathrm{Ni}$ and $\mathrm{Zn}(p<0.05$; Scheffes test) were observed between Sites A and C and between Sites B and C at Week 3 (Table 2).

\section{Metal levels in fish tissues}

$\mathrm{Pb}, \mathrm{Ni}, \mathrm{Cu}, \mathrm{Co}$ and $\mathrm{Zn}$ levels were high in the tilapia abdominal muscle at Week 6 (Table 3). Low levels of metals were found at the control site for the duration of the study. Bioconcentration values comparing metal concentrations in fish tissues and water were nearly all in the range of 1-1 000 while high values of > 1000 were recorded for Co and Cd at Site C and Week 3. Co and Cd had extremely high values in Sites A, B and C at Week 3 , while at Week $6 \mathrm{Co}$ and $\mathrm{Cd}$ had high bioconcentration values (Table 4).

Fish biomarker responses HSP 70 Protein and GST activity in tissues differed significantly ( $p<0.05$; Kruskall Anova) amongst sites. Spearman rank correlation and Kendall Tau permutations revealed significant $(p<0.05)$ relationships between GST activity and $\mathrm{Pb}(p=0.03), \mathrm{Cu}(p=0.001), \mathrm{Cd}(p=0.004)$ and $\mathrm{Zn}(p=0.02)$. $\mathrm{Ni}$ and $\mathrm{Co}$ had no significant relationships with GST activity whilst HSP 70 protein activity was significantly correlated ( $p<0.05$; Spearman and Kendall Tau tests) with all the metals under study: $\mathrm{Pb}(p=0.01), \mathrm{Cu}(p=0.02), \mathrm{Cd}$

\begin{tabular}{|l|c|c|c|c|c|c|c|}
\hline \multicolumn{9}{|c|}{ Metal concentration (ppb) in water in the Pote River. The WHO limits are given for each metal } \\
\hline Week & Site & $\mathbf{P b} / \mathbf{5 . 0 0}$ & $\mathbf{N i} / \mathbf{0 . 0 0 3}$ & $\mathbf{C u} / \mathbf{2 . 0 0}$ & $\mathbf{C o} / \mathbf{0 . 0 5}$ & $\mathbf{C d} / \mathbf{3 . 0 0}$ & Zn/0.01 \\
\hline 0 & Control & $0.38 \pm 0.7$ & $1.78 \pm 0.0$ & $1.43 \pm 0.1$ & $0.04 \pm 0.0$ & $0.04 \pm 0.0$ & $1.09 \pm 0.0$ \\
\cline { 2 - 9 } & A & $0.32 \pm 0.1$ & $1.13 \pm 0.0$ & $0.98 \pm 0.0$ & $0.03 \pm 0.1$ & $0.02 \pm 0.1$ & $1.03 \pm 0.1$ \\
\cline { 2 - 9 } & B & $1.23 \pm$ & $1.15 \pm 0.0$ & $1.45 \pm 0.1$ & $0.05 \pm 0.0$ & $0.02 \pm 0.0$ & $0.56 \pm 0.4$ \\
\cline { 2 - 9 } & C & $0.99 \pm 0.0$ & $1.06 \pm 0.1$ & $1.07 \pm 0.6$ & $0.02 \pm 0.1$ & $0.02 \pm 0.1$ & $1.07 \pm 0.5$ \\
\hline 3 & Control & $0.42 \pm 0.0$ & $1.81 \pm 0.0$ & $1.26 \pm 0.0$ & $0.05 \pm 0.0$ & $0.04 \pm 0.0$ & $1.18 \pm 0.0$ \\
\cline { 2 - 9 } & A & $1.68 \pm 0.0$ & $0.52 \pm 0.0$ & $0.89 \pm 0.0$ & $0.04 \pm 0.0$ & $0.01 \pm 0.0$ & $0.21 \pm 0.0$ \\
\cline { 2 - 8 } & B & $1.26 \pm 0.0$ & $2.37 \pm 0.0$ & $1.96 \pm 0.0$ & $0.10 \pm 0.0$ & $0.01 \pm 0.0$ & $0.21 \pm 0.0$ \\
\cline { 2 - 8 } & C & $0.28 \pm 0.0$ & $2.04 \pm 0.0$ & $1.96 \pm 0.0$ & $0.09 \pm 0.0$ & $0.05 \pm 0.0$ & $1.31 \pm 0.0$ \\
\cline { 2 - 8 } & Control & $0.29 \pm 0.0$ & $0.72 \pm 0.0$ & $0.93 \pm 0.0$ & $0.04 \pm 0.0$ & $0.04 \pm 0.0$ & $0.47 \pm 0.0$ \\
\cline { 2 - 8 } & A & $0.28 \pm 0.0$ & $0.52 \pm 0.0$ & $0.89 \pm 0.0$ & $0.04 \pm 0.0$ & $0.01 \pm 0.0$ & $0.21 \pm 0.0$ \\
\cline { 2 - 8 } & B & $0.42 \pm 0.0$ & $0.96 \pm 0.0$ & $1.02 \pm 0.0$ & $0.06 \pm 0.0$ & $0.05 \pm 0.0$ & $0.60 \pm 0.0$ \\
\cline { 2 - 8 } & C & $0.31 \pm 0.0$ & $0.94 \pm 0.0$ & $0.99 \pm 0.0$ & $0.05 \pm 0.0$ & $0.04 \pm 0.0$ & $0.50 \pm 0.0$ \\
\hline
\end{tabular}

\begin{tabular}{|c|c|c|c|c|c|c|c|}
\hline \multicolumn{8}{|c|}{$\begin{array}{l}\text { Table } 3 \\
\text { Metal concentration (ppm ww) in fish tissues in the Pote River over a 6-week period }\end{array}$} \\
\hline Week & Site & $\mathbf{P b}$ & $\mathrm{Ni}$ & $\mathrm{Cu}$ & Co & Cd & $\mathrm{Zn}$ \\
\hline \multirow[t]{4}{*}{0} & Control & 3.18 & 5.08 & 6.98 & 5.53 & 71.02 & 3 \\
\hline & $\mathrm{A}$ & 131 & 268 & 239 & 179 & 142 & 132 \\
\hline & B & 129 & 197 & 203 & 132 & 147 & 131 \\
\hline & $\mathrm{C}$ & 98 & 135 & 153 & 122 & 117 & 116 \\
\hline \multirow[t]{4}{*}{3} & Control & 3.35 & 5.17 & 7.05 & 4.32 & 3.16 & 8 \\
\hline & A & 136.33 & 278.33 & 233.33 & 182 & 145 & 143 \\
\hline & B & 120 & 199.50 & 193 & 147.5 & 149.50 & 126 \\
\hline & C & 99 & 124 & 157 & 126 & 120.50 & 120.50 \\
\hline \multirow[t]{4}{*}{6} & Control & 4.09 & 14 & 5.67 & 2.5 & 2.3 & 2.66 \\
\hline & A & 177.33 & 362.66 & 306 & 235 & 130.66 & 127.66 \\
\hline & B & 135.33 & 307.33 & 210.67 & 216.33 & 117 & 115.66 \\
\hline & C & 107.67 & 205 & 174 & 210.66 & 105.33 & 102.67 \\
\hline
\end{tabular}




\begin{tabular}{|c|c|c|c|c|c|c|}
\hline \multicolumn{7}{|c|}{$\begin{array}{c}\text { Table } 4 \\
\text { Metal bioconcentration factors in fish tissues relative to water in the Pote River }\end{array}$} \\
\hline \multirow{5}{*}{$\begin{array}{l}\text { Week } \\
0\end{array}$} & Site & $\mathbf{P b}$ & $\mathbf{N i}$ & $\mathrm{Cu}$ & Co & Cd \\
\hline & Control & 7.5 & 2.8 & 5.62 & 3.8 & 75.26 \\
\hline & A & 85.2 & 512.5 & 256.18 & 4063.26 & 28400 \\
\hline & B & 95.7 & 83.2 & 103.7 & 1306.9 & 2805.34 \\
\hline & $\mathrm{C}$ & 355.5 & 66.1 & 75.94 & 1416.95 & 2560.17 \\
\hline \multirow[t]{4}{*}{3} & Control & 7.91 & 2.85 & 5.54 & 79.95 & 88.95 \\
\hline & $\mathrm{A}$ & 81.24 & 531.73 & 263.52 & 4480.04 & 30483.6 \\
\hline & B & 98.07 & 84.249 & 98.62 & 1466.24 & 2854.24 \\
\hline & $\mathrm{C}$ & 358.61 & 60.74 & 82.63 & 1460.24 & 2663.19 \\
\hline \multirow[t]{4}{*}{6} & Control & 13.76 & 19.34 & 6.07 & 55.88 & 62.51 \\
\hline & A & 642.88 & 693.04 & 342.4 & 5635.67 & 27353.60 \\
\hline & B & 320.03 & 319.25 & 205.88 & 3557.98 & 2420.56 \\
\hline & $\mathrm{C}$ & 350.58 & 217.66 & 174.73 & 4282.87 & 2801.25 \\
\hline
\end{tabular}

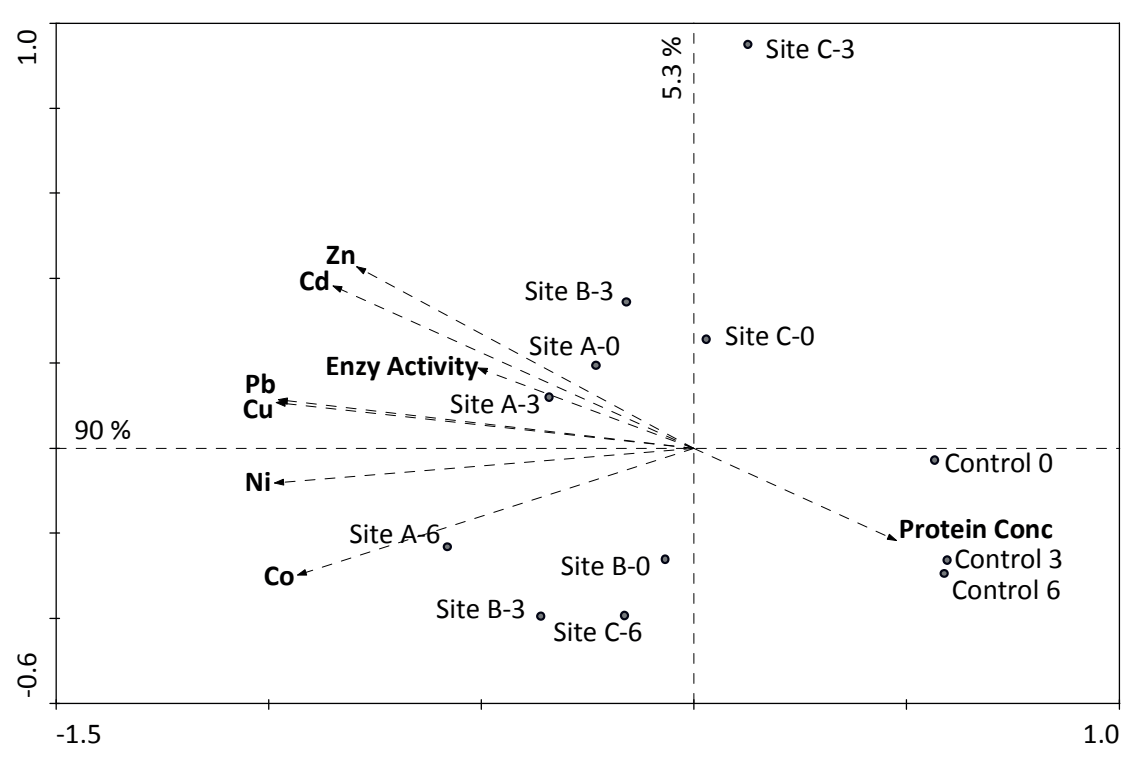

Figure 2

Principal component analysis based on metal levels in the water column, GST activity and HSP 70 concentration in the fish at Sites A, B, C and the control during the three sampling periods (0,3 and 6 weeks)

$(p=0.001), \mathrm{Ni}(p=0.02)$ and $\mathrm{Zn}(p=0.02)$ except for Co. For the entire sampling period the PCA separated Sites A and B from the control. High metal levels and GST activity were negatively associated with the first axis which accounted for $90 \%$ of the total variation, while HSP 70 concentration was negatively associated with the first axis. Sites A and B were associated with low HSP 70 concentration, high metal levels and GST activity. The control was associated with high HSP 70 concentrations, low metal levels and GST activity. High metal levels (Cd and Zn) were associated with high GST activity and low HSP 70 concentrations (Fig. 2).

\section{DISCUSSION}

The main aim of this study was to establish the level of impairment along a mining effluent receiving river, Pote River, using
Oreochromis niloticus as an indicator organism, whilst the expression of HSP 70 protein and glutathione-S-transferase (GST) labelled as enzymatic activity were used as surrogate biomarkers of heavy metal contamination. Water quality parameters showed differences between sites away from the point of discharge. Conductivity and TDS were high and DO low at Sites A, B and C due to mine effluent pollution. Although the main polluter of the river is Bindura Nickel Mine which primarily mines $\mathrm{Ni}$, other by products such as $\mathrm{Zn}$, Co and $\mathrm{Cd}$ were detected along the Pote River.

The concentration of $\mathrm{Ni}, \mathrm{Co}$ and $\mathrm{Zn}$ in flowing water were considerably higher than the World Health Organization aquatic effluent standards. Thornton and Nduku (1982) concluded that the main source of $\mathrm{Zn}, \mathrm{Ni}$ and $\mathrm{Fe}$ in the Pote River and the downstream Gwebi River was the underlying banded ironstones that traverse much of the northern part of the upper 
Zambezi River catchment, which is the main watershed area for the Mazowe River. In addition, the Pote River watershed is influenced by the Great Dyke, a linear geological feature that trends nearly north-south through the centre of Zimbabwe, passing just to the northwest of Harare and containing vast ore deposits such as iron, gold, silver, chromium, platinum, nickel and asbestos (Nhiwatiwa et al., 2011)

The increasing order of metal concentration in water was $\mathrm{Ni}>\mathrm{Cu}>\mathrm{Zn}>\mathrm{Pb}>\mathrm{Co}>\mathrm{Cd}$, which was similar to that in Tilapia fish tissue exposed to polluted water in the Pote River. This implies that Tilapia can be a useful bioindicator organism to identify metal contamination in rivers. Metal concentration in fish tissues was high at all of the sites sampled at Week 6, suggesting that there is bioaccumulation of metals in Tilapia fish tissue. Studies by Haiyan and Stuanes (2003) and Nhiwatiwa et al. (2011) showed that metals accumulate at a rate correlated to exposure duration and depuration mechanisms of the test organism. However, our findings show that metal accumulates in stomach tissues which is contrary to assertions by Legoburn et al. (1988) and Benson et al. (2007).

HSP 70 protein activity and GST enzyme activity differed significantly ( $p<0.05$; Kruskall Wallis Anova) in the muscle tissue collected at different sites. Principal component analysis of metal correlation to biomarker responses indicated that the principal metals related to protein activity were $\mathrm{Co}, \mathrm{Ni}$ and $\mathrm{Cu}$ whilst the enzymatic activity was mainly associated with $\mathrm{Cd}, \mathrm{Zn}$ and $\mathrm{Pb}$. These findings show that there is potential to use stress protein expression and enzyme activity in fish as biomarkers of metal contamination in lotic systems. Wepener et al. (2005), Farombi et al. (2007) and Siwela et al. (2009) have shown that stress proteins are sensitive indicators of sublethal exposure to contaminants in the environment. Stress proteins are synthesized at higher levels when cells are stimulated with certain environmental parameters, such as high temperature and toxic chemicals (Cruz-Rodriguez and $\mathrm{Chu}, 2002$ ), and the cells then undergo alterations in gene expression in response to environmental stressors (Huggett et al., 1992). The stress protein response is a potentially useful marker in combination with a suite of biomarkers in toxicological studies. Heat shock proteins (HSPs), particularly HSP 60 and HSP 70, have been suggested as useful biomarkers of environmental contaminants (Sanders, 1993; Clayton et al., 2000).

Significant relationships between enzyme activity and heavy metal $(\mathrm{Pb}, \mathrm{Cu}, \mathrm{Cd}$ and $\mathrm{Zn})$ concentrations in stomach fish tissue were observed at all of the sites sampled in the Pote River. Biochemical and physiological indicators such as enzymes can be used to identify possible environmental problems before aquatic system health is seriously altered (Jiminez and Stegeman, 1990). The measurement of enzyme concentrations is a classical means by which the health of fish populations is assessed in different water sources (Landis and $\mathrm{Yu}, 1995$ ) and has been exploited in assessing the effects of pollution on fish (Adams, 2001; Kaoud and El-Dahshan, 2010).

$\mathrm{Ni}$ and Co concentrations had no significant correlation with enzyme activity while other metals had a significant positive and negative relationship with enzyme activity and stress protein quantity. This highlights the significance that other factors, like the oxidation state and depuration rates (Ekweozo et al., 2003; Haiyan and Stuanes, 2003), play in the bioaccumulation of metals in aquatic organisms. The principal metals identified to be related with protein activity were $\mathrm{Co}, \mathrm{Ni}$ and $\mathrm{Cu}$ whilst the enzymatic activity was mainly associated with
$\mathrm{Cd}, \mathrm{Zn}$ and $\mathrm{Pb}$. Clayton et al. (2000) found increasing concentrations of HSP 60 and HSP 70 as a result of increasing tissue concentrations of $\mathrm{Cu}$ and tributylin in zebra mussels in the laboratory.

The time period of sampling appears to have had no significant relationship with enzyme activity, protein quantity and metal concentration in this study. Metal bioaccumulation and bioconcentration values were different in the pectoral muscles of the Tilapia in the Pote River and this may be caused by differences in the metal concentration due to the natural purification capacity of the river and different sedimentation and re-suspension rates in lotic waters (Moyo and Phiri, 2002; Nhiwatiwa et al., 2011). $\mathrm{Co}, \mathrm{Cu}, \mathrm{Cd}$ and $\mathrm{Ni}$ had high bioconcentration factors in the pectoral muscle measured relative to water. This, to a certain extent, shows that there is potential to use metal concentrations in fish tissues as indicators of metal contamination in the aquatic habitat. Results of this study have shown that HSP 70 protein activity and GST enzyme activity can be used as potential biomarkers of metal contamination in lotic systems.

\section{ACKNOWLEDGEMENTS}

Our sincere thanks go to all members of the Biochemistry Department, University of Zimbabwe, who in their own ways helped us to analyse our fish specimens.

\section{REFERENCES}

ADAMS SM (2001) Biomarker/bioindicator response profiles of organisms can help differentiate between sources of anthropogenic stressors in aquatic ecosystems. Biomarkers $633-44$

ADEDEJI OB, ADEYEMO OK, and OYEDELE MO (2011) Heavy metals in snail and water samples from Alaro River in Oluyole Industrial Area of Ibadan, southwestern Nigeria. J. Appl. Sci. Environ. Sanit. 6 (2) 115-121.

ADENIYI AA (2008) Assessment of the exposure of two fish species to metals pollution in the Ogun river catchments, Ketu, Lagos, Nigeria. Environ. Monit. Assess. 137 451-458.

ALI, A, DODO A, BOUBA A, CLEMENT S and TENIN D (2010) Determination of minerals and heavy metals in water, sediments and three fish species (Tilapia niloticus, Silurus glanis and Arius parkii) from Lagdo Lake Cameroun. J. Fish. Int. 53 54-57.

AMARANEMI S (2006) Distribution of pesticides, PAHs and heavy metals in prawn ponds near Kolleru lake wetland, India. Environ. Int. 32 294-302.

BENSON NU, ESSIEN JP, WILLIAMS AB and BASSEY DE (2007) Mercury accumulation in fishes from tropical aquatic ecosystems in the Niger Delta, Nigeria. Curr. Sci. 92 (25) 781-785.

BRADFORD MB (1976) A rapid and sensitive method for quantification of microgram quantities of protein utilising the principle of protein dye binding. Anal. Biochem. 72 248-254.

CLAYTON ME, STEINMANN R and FENT K (2000) Different expression patterns of heat shock proteins HSP 60 and HSP 70 in Zebra mussels (Dressena polymorpha) exposed to copper and tributylin. Aquat. Toxicol. 47 213-226.

CRUZ-RODRIGUEZ LA and CHU FE (2002) Heat-shock protein (HSP 70) response in the eastern oyster, Crassotrea virginica, exposed to PAHs sorbed to suspended artificial clay particles and to suspended field contaminated sediments. Aquat. Toxicol. 60 157-168.

EGBON EE, JATTO EO, ASIA IO and IZE-IYAMU O K (2006) Proximate and mineral composition of Mucuna prurient. Chem. Technol. J. 3 640-642.

EKWEOZOR IKE, DAMBO WB and DAKA ER (2003) Zinc and cadmium in Crassostrea gasar from the lower Bonny Estuary, Nigeria. J. Nig. Environ. Soc. 1 31-40.

FAROMBI EO, ADELOWO OA and AJIMOKO YR (2007) Biomarkers of oxidative stress and heavy metal levels as indicators of 
environmental pollution in African cat fish (Clarias gariepinus) from Nigeria Ogun River. Int. J. Environ. Res. Public Health 4 158-165.

HAMMER O, HARPER DAT and RYAN PD (2012) PAST -

Palaeontological Statistics, version 1.90. URL: http://folk.uio.no/ ohammer/past.

HAIYAN W and STUANES AO (2003) Heavy metal pollution in airwater-soil plant system of Zhuzhou City, Human Province, China. Water, Air Soil Pollut. 149 51-75.

HOOK SE (2001) Sublethal toxicity of metals to copepods. PhD thesis, State University of New York, New York.

HOOK SE and FISHER NS (2002) Relating the reproductive toxicity of five ingested metals in calanoid copepods with sulfur affinity. Mar. Environ. Res. 53 161-174.

HUGGETT RJ, KIMERLIE R A, MEHRLE JRPM and BERGMAN HL (1992) Biomarkers: Biochemical, Physiological and histological Markers of Anthropogenic Stress. Lewis Publishers, Boca Raton. 347 pp.

IWEGBU CMA, NWAJEI GE and ISIRIMAH NO (2007) Characteristic levels of heavy metals in sediments and dredged sediments of a municipal creek in Nigeria. Environmentalist 26 139-141.

JATTO OE, ASIA IO and MEDJOR WE (2010) Proximate and minera composition of different species of snail shell. Pac. J. Sci. Technol. 11 (1) 416-419

JIMINEZ BD and STEGEMAN JJ (1990) Detoxification enzymes as indicators of environmental stress on fish. Am. Fish. Soc. Symp. 8 67-79.

KAOUD HA and EL-DAHSHAN AR (2010) Bioaccumulation and histopathological alterations of the heavy metals in Oreochromis niloticus fish. Nat. Sci. 8 (4) 147-156.

LANDIS WG and YU M (1995) Introduction to Environmental Toxicology: Impacts of Chemicals upon Ecological Systems. Lewis Publishers, Boca Raton.
LEGORBURU I, CANTON L, MILLAN E and CASADO A (1988) Trace metal levels in fish from Unda river (Spain) Anguillidae, Mugillidae and Salmonidae. Environ. Technol. Lett. 41 1373-1378.

MOYO NA G and PHIRI C (2002) The degradation of an urban stream in Harare, Zimbabwe. Afr. J. Ecol. 40 401-404.

NHIWATIWA T, BARSON M, HARRISON AP, UTETE B and COOPER RG (2011) Metal concentrations in water, sediment and sharp tooth catfish Clarias gariepinus from three peri-urban rivers in the upper Manyame catchment, Zimbabwe. Afr. J. Aquat. Sci. 36 (3) 243-252.

SANDERS BM (1993) Stress proteins in aquatic organisms. An environmental perspective. Crit. Rev. Toxicol. 23 49-75.

TER BRAAK CJF and ŠMILAUER P (2002) CANOCO Reference Manual and CanDraw for Windows User's Guide: Software for community ordination, version 4.5. Microcomputer Power, Ithaca, New York.

THORNTON JA and NDUKU W (1982) Water quality chemistry and nutrient budgets. In: Thornton JA. (ed.) Lake Mcllwaine: The Eutrophication and Recovery of a Tropical African Lake. University of Zimbabwe Publications, Harare. 34-43.

WEPENER V, VAN VUREN, JHJ, CHATIZA FP, MBIZI Z, SLABBERT L and MASOLA B (2005) Active biomonitoring in freshwater environments: early warning signals from biomarkers in assessing biological effects of diffuse sources of pollutants. Phys. Chem. Earth 30 751-761.

WIENER JG and GIESY JP (1979) Concentrations of Cd, Cu, Mn, Pb and $\mathrm{Zn}$ in fishes in a highly organic softwater pond. J. Fish Res. 35 270-279. 